\title{
IMAN KRISTIANI KEPADA ALLAH YANG SATU
}

\author{
Paulus Bagus Sugiyono*
}

\begin{abstract}
Abstrak
Penghayatan iman umat Kristiani begitu khas. Umat Kristiani percaya kepada Allah yang Satu. Untuk menjelaskan pernyataan ini, penulis menggunakan bahan bacaan berupa bagian buku tulisan Joseph Ratzinger (Paus Benediktus XVI) yang berjudul Prolegomena to the Subject of God. Berbicara mengenai Allah yang Satu dalam kepercayaan Kristiani, kita tentu tidak dapat melepaskan diri dari konsep yang khas, yakni Allah Tritunggal.
\end{abstract}

Kata Kunci: Iman, Kristiani, monoteisme, Allah, Tritunggal.

\section{Pengantar}

Dalam era globalisasi sekarang ini, ada dua kecenderungan ekstrim yang dapat terjadi dalam kehidupan iman seorang manusia. Ekstrim pertama adalah penyangkalan keberadaan Dia yang Absolut. Pandangan ini muncul ketika Dia yang Absolut hendak dibuktikan dengan eksperimen laboratorium atau diukur dalam kategori matematis. ${ }^{1}$ Alih-alih mencari jejak-jejak keberadaan Dia yang Absolut, manusia jatuh pada obsesi positivis yang berlebihan. Kita kemudian tahu bahwa pandangan ini tidak lain disebut dengan ateisme. Manusia menolak keberadaan Dia yang Absolut. Ekstrim yang kedua adalah pemujaan berlebihan terhadap tuhan-tuhan. Ada banyak objek tuhan yang dipuja dan disembah. Objek tuhan-tuhan yang dipuja dan disembah ini tentu tidak lagi sama dengan objek yang dipuja ribuan

1 Joseph Ratzinger dalam Krispurwana Cahyadi, Benediktus XVI (Yogyakarta: Kanisius, 2010), 190. 
tahun yang lalu (misalnya dewa-dewi). Seiring perkembangan teknologi, politik, dan budaya, objek-objek tersebut kini telah berubah menjadi materi-materi profan atau duniawi, seperti kekuasaan, kekayaan dan nafsu seksual.

Pertanyaan yang pantas diajukan kemudian adalah: Bagaimana umat beriman Kristiani lantas mengambil posisinya? Di dalam tulisan berikut, penulis akan membahas mengenai ajaran iman Kristiani sebagai pegangan umat beriman di era globalisasi berdasarkan pandangan Joseph Ratzinger (Paus Benediktus XVI). Bahan utama yang dijadikan acuan oleh penulis adalah bagian pertama buku Introduction to Christianity karangan Joseph Ratzinger yang berjudul Prolegomena to the Subject of God. Bagian pertama buku ini terdiri dari dua sub bagian, yakni The Scope of the Question dan The Profession of Faith in the One God. Dalam tulisan tersebut, Joseph Ratzinger hendak menyampaikan pandangannya mengenai ajaran iman Kristiani sebagai pegangan umat beriman di era globalisasi.

Secara praktis, tulisan berikut akan penulis bagi ke dalam lima bagian besar. Yakni; (1)sekilas tentang Joseph Ratzinger dalam kaitannya dengan iman Kristiani, (2)Tuhan sebagai sumber utama hidup umat Kristiani, (3)monoteisme, politeisme, dan ateisme, (4)pengakuan iman akan satu Tuhan, dan (5)Allah Bapa, Putera dan Roh Kudus.

\section{Sekilas tentang Joseph Ratzinger dalam Kaitannya dengan Iman Kristiani}

Joseph Ratzinger adalah seorang tokoh modern Gereja yang banyak bergelut di bidang iman. Pada tanggal 25 November 1981, Paus Yohanes Paulus II menunjuk Kardinal Ratzinger ini sebagai Prefek Kongregasi untuk Ajaran Iman. ${ }^{2}$ Olah pikirnya seakan mengalir dan

2 Libertus Jehani, Paus Benediktus XVI: Palang Pintu Iman Katolik (Tangerang: Sinondang Media, 2005), 16-17. 
terisi oleh pikiran tentang moral, iman, dan masalah-masalah aktual dunia. Kebenaran-kebenaran ajaran Kristiani tentang Trinitas, kitab suci, dan syahadat para rasul yang harus dijelaskan dengan rumit oleh banyak pemikir dapat diungkapkan olehnya secara sederhana tanpa mengurangi makna dan substansi ajaran itu sendiri. ${ }^{3}$

Ketika kecenderungan terjadinya relativisme dalam iman yang seakan-akan dipahami sebagai buah dari toleransi semakin menguat, Ratzinger membedakannya secara jelas dan mendalam. Dalam kaitannya dengan fenomena menguatnya relativisme iman itulah ia juga menganalisis secara mendalam dan komprehensif tentang situasi Eropa modern. Kardinal Ratzinger terpanggil untuk menyatakan secara terbuka dan jujur mengenai apa yang terjadi di Eropa yang pada masa silam menjadi benua paling subur dalam perkembangan ajaran-ajaran Kristen. Ratzinger melihat bahwa di Eropa kini sedang terjadi bahaya besar, yakni relativisme iman secara mendalam. ${ }^{4}$

\section{Tuhan sebagai Sumber Utama Hidup Umat Kristiani}

Di dalam bagian pertama buku berjudul Introduction to Christianity, Ratzinger menjelaskan tentang Tuhan sebagai subyek atau sumber utama hidup umat kristiani. Ratzinger berusaha menyingkap eksistensi Tuhan dan pengaruh-Nya dalam hidup manusia dari balik pertanyaan-pertanyaan di sekitar topik tersebut. Usaha ini dilakukan demi tersedianya dasar-dasar hidup beriman kristiani yang baik dan benar.

Dewasa ini, perdebatan dan diskusi telah banyak dilakukan untuk mengupas eksistensi Tuhan dalam hidup manusia. Salah satu hasilnya menunjukkan bahwa saat ini subyek "Tuhan" terdapat dalam tiga bentuk variasi yang dianut oleh umat manusia, yakni monoteisme,

\footnotetext{
${ }^{3}$ Libertus Jehani, Paus Benediktus XVI: Palang Pintu Iman Katolik, 30-1.

${ }^{4}$ Libertus Jehani, Paus Benediktus XVI: Palang Pintu Iman Katolik, 31-2.
} 
politeisme, dan ateisme. Ratzinger menekankan bahwa sebenarnya ketiga macam teisme tersebut semakin jelas menampakkan sebuah kesatuan yang mendasar. Kesatuan yang mendasar itu adalah pengakuan iman bahwa hanya ada satu Tuhan. Konsekuensinya, penolakan akan adanya tuhan-tuhan atau dewa-dewa lain harus dilakukan. Namun, penolakan tersebut tidak serupa dengan fanatisme yang dangkal (narrow-minded fanaticism).

Ratzinger dengan lugas memberikan pedoman hidup Kristiani yang baik dan benar. Ratzinger memulai bagian pertama bukunya dengan memunculkan beberapa pertanyaan awal yang mendasar (fundamental preliminary questions) terkait eksistensi Tuhan. Pertanyaanpertanyaan tersebut dapat dijawab dengan terlebih dahulu mendeskripsikan dua akar kehidupan umat Kristiani. Akar pertama yang perlu dideskripsikan adalah pengalaman keberadaan manusia itu sendiri (human existence). Ratzinger mengutip tulisan seorang teolog bernama Dietrich Bonhoeffer untuk memberikan penjelasan lebih lanjut terkait akar ini. Bonhoeffer mengatakan bahwa waktunya telah tiba untuk menghentikan kondisi di mana manusia "menggunakan" Tuhan untuk "mengisi" keterbatasannya. Hanya di akhir-akhir kesulitan manusia (the end of our tether) sajalah manusia ingat akan Tuhan. Manusia tidak seharusnya mencari Tuhan dalam kelemahan atau kesulitan (desolasi), melainkan dalam kepenuhan dan situasi gembira (konsolasi). Bonhoeffer selanjutnya menjelaskan tiga kualitas yang menunjukkan relasi yang baik antara manusia dengan Tuhan. Ketiga kriteria itu adalah memahami Tuhan melalui berkat yang diberikanNya, menjalin relasi Tuhan dalam kepenuhan manusia, dan berbelarasa dengan Tuhan dalam penderitaan-Nya di dunia. ${ }^{5}$

${ }^{5}$ Isaac C. Rottenberg, "Religionless Christianity", http:/ /www.religiononline.org/showchapter.asp?title $=1752 \& C=1513$ (diakses tanggal 17 November 2014 pukul 20.52 WIB). Rottenberg menuliskan, “... he (Bonhoeffer) suggests three qualities which describe the Christian's relationship to God: knowing God in the blessings He sends us; relating to God in strength, and not in weakness; and sharing with God in His suffering in the world..." . 
Paulus Bagus Sugiyono, Iman Kristiani Kepada Allah Yang Satu

Ratzinger melanjutkan bahwa kedua situasi (desolasi dan konsolasi) tersebut sebenarnya dapat menjadi sarana bagi manusia untuk bertemu dengan Tuhan dalam eksistensi dirinya. Ketika manusia berada dalam kepenuhan dirinya, manusia menjadi sadar bahwa ia perlu berterima kasih pada Yang Ilahi atas keberadaannya tersebut. Segala kepenuhan hidup bukanlah sesuatu yang dapat diraih oleh manusia, melainkan semata-mata merupakan pemberian dari Yang Ilahi kepada manusia sebelum manusia berbuat sesuatu. Di lain situasi, pengalaman keterbatasan manusia (being limited) membuat manusia sadar bahwa dirinya adalah makhluk yang terbatas (he is not selfsufficient). Manusia harus keluar dari dalam dirinya sendiri dan bergerak menuju Yang Ilahi (moving toward the entirely Other and infinitely greater). Seluruh penjelasan tersebut menegaskan bahwa keberadaan manusia dapat menjadi titik pijak untuk berjumpa dan mengalami Yang Absolut/Ilahi, yang dalam sudut pandang ini dilihat sebagai "Allah Putera" sebagai penyelamat atau secara lebih sederhana dikatakan sebagai Allah yang terkait dengan keberadaan manusia.

Akar kedua adalah perjumpaan atau konfrontasi manusia dengan dunia, di dalam "pertempuran" antara yang baik dan jahat. Dunia menawarkan "koin bersisi dua" di mana manusia dapat merasakan pengalaman baik dan sekaligus tidak baik. Di dalamnya, manusia dapat bertumbuh untuk semakin dewasa dan bijaksana. Pengalaman perjumpaan dengan dua pengalaman yang saling berkebalikan itulah yang mengasah dan menumbuhkembangkan pribadi manusia.

\section{Monoteisme, Politeisme, dan Ateisme}

Isu yang kemudian muncul terkait dengan proses pemaknaan Tuhan dalam sejarah hidup manusia adalah adanya tiga bentuk teisme, yakni monoteisme, politeisme, dan ateisme. Ratzinger meyakini bahwa 
pertanyaan-pertanyaan yang muncul terkait eksistensi Tuhan dapat didalami dengan memulai pembahasan akan ketiga bentuk teisme tersebut. Saat ditelusuri secara lebih mendalam dan teliti, Ratzinger menemukan bahwa ketiga aliran tersebut justru meyakinkan adanya kesatuan (unity) dan Ia yang absolut.

Bukan hanya monoteisme yang meyakini adanya kesatuan (unity) dan Dia yang satu, tetapi juga politeisme dan ateisme. Meskipun politeisme meyakini dan percaya akan adanya banyak dewa atau tuhan, secara langsung maupun tidak langsung politeisme juga meyakini bahwa di suatu tempat atau di balik banyaknya kekuatan, dewa, atau tuhan terdapat Dia yang satu (one Being). "Dia" yang satu itulah yang menjadi kekuatan penopang kekuatan-kekuatan lainnya. Selain politeisme, ateisme juga menyatakan keesaan yang Absolut. Penolakanpenolakan eksistensi Tuhan yang dilakukan oleh kaum ateis tanpa disadari bersikap kontra produktif. Penolakan tersebut semakin mengukuhkan adanya Tuhan atau Sesuatu yang Absolut. Kaum ateis jelas tidak dapat menolak sesuatu tanpa sebelumnya sesuatu tersebut bereksistensi terlebih dahulu. Satu-satunya perbedaan di antara ketiga aliran tersebut, menurut Ratzinger, terletak pada gagasan tentang bagaimana mereka memandang yang Absolut. Dengan kata lain, perbedaan terletak pada bagaimana mereka memaknai tindakan yang Absolut dalam hidup manusia.

Ratzinger mengutip sebuah contoh tegangan yang dapat terjadi di antara kedua akar tersebut. Kutipan ini berasal dari seorang ahli fenomenologi keagamaan dari Belanda bernama van der Leeuw. Leeuw menyatakan bahwa dalam sejarah hidup iman kristiani, Allah Putera ada sebelum Allah Bapa. Konsekuensinya, Allah sebagai penyelamat dan penebus hadir lebih dahulu daripada Allah sebagai pencipta. Ratzinger menilai bahwa pernyataan ini tentu bersifat tidak sahih, sebab tidak ada pembuktian yang cukup kuat untuk mendukungnya. 


\section{Pengakuan Iman akan Satu Tuhan}

Pengakuan iman akan adanya satu Tuhan menjadi dasar iman bagi kehidupan umat Kristiani. Ratzinger mencoba menjelaskannya dengan merujuk pada rumusan iman para rasul (Aku Percaya). Rumusan iman ini adalah hasil dari sejarah di masa lalu yang masih diakui umat Kristiani selama hampir dua ribu tahun sampai sekarang ini. Di balik pengakuan iman ini, terdapat pengakuan iman Bangsa Israel yang kira-kira berbunyi, "Dengarlah oh Israel, Yahwe, Allahmu adalah satu-satunya Allah" (Hear, O Israel, Yahweh, thy God, is an only God). Perjuangan, pengalaman iman, dan pergulatan bangsa Israel dengan Tuhan inilah yang diadaptasi oleh umat Kristiani sampai saat ini.

Pengakuan iman bahwa hanya ada satu Allah merupakan sesuatu yang mendasar, membentuk iman, dan menjadi pegangan umat Kristiani. Jawaban "ya" kepada Allah yang satu itu menepikan allahallah yang lain di tengah dunia ini. Tiga obyek pemujaan yang biasanya bergerak sebagai "allah-allah lain" saat ini adalah harta, tahta dan nafsu seks. Pemujaan terhadap ketiga hal ini jelas merupakan sebuah penyimpangan sebab mengabsolutkan apa yang seharusnya tidak absolut di dalam ketiga hal tersebut. Manusia sendiri turun kodratnya sebab menghambakan dirinya sendiri kepada tiga hal tersebut. Seorang teolog Kristen, J.L. Ch. Abenano menegaskan bahwa umat beriman tidak ingin lagi menyembah dan melayani allah-allah lain tersebut. Umat beriman hanya ingin menyembah dan melayani Allah saja sebagai satusatunya Allah. Dengan demikian, terjalin hubungan antar pribadi yang kemudian dimaksudkan dalam Syahadat dengan istilah "percaya" ${ }^{6}$

6 J.L. Ch. Abenano dalam Nico Syukur Dister, Pengantar Teologi (Yogyakarta: Kanisius, 1991), 141-2. 
Selain penolakan terhadap dewa-dewa lain di sekitar (renunciation of the surrounding gods), Ratzinger juga menegaskan bahwa hal ini juga mengimplikasi adanya penolakan terhadap pemujaan (deitification) terhadap kekuatan politik dan siklus kosmos "mati dan menjadi" (stirb und werde/die and become). Ratzinger menegaskan bahwa pengakuan iman akan Tuhan yang satu membawa konsekuensi untuk melepas "pemujaan" terhadap kekuatan politik yang berlebihan dan hendak menindas rakyat. Salah satu pengalaman penindasan tersebut, misalnya ketika umat Kristen dikejar dan dibunuh oleh kekaisaran Romawi dalam masa awal Gereja Kristen. Dalam pemaknaan yang lain tentang kekuasaan politik, Ratzinger mengatakan bahwa pengakuan iman akan Tuhan yang satu tidak sama dengan kekuatan politik yang absolut/otoriter atau tirani. Alasannya adalah karena pengakuan iman akan satu Tuhan tidak punya tujuan politik apapun, yang sampai saat ini kerap dimaknai sebagai pelestarian kekuasaan, pencarian keuntungan, dsb. Maka, penggunaan nama Tuhan demi kepentingankepentingan tersebut jelas bukanlah tindakan yang terpuji.

Namun, hal ini tidak berarti bahwa Ratzinger adalah pribadi yang anti pemerintah atau politik. Sebagai umat Kristen yang baik dan benar, partisipasi dalam pemerintahan dan politik adalah sesuatu yang mengembangkan iman. Yang ingin ditekankan oleh Ratzinger adalah umat Kristiani harus menyesuaikan praktek iman Kristiani dengan kondisi zaman sekarang atau konteks yang sesuai (proper context). Dengan demikian, manusia tidak menjelma menjadi pribadi yang memiliki fanatisme yang dangkal (narrow-minded fanaticism) terhadap imannya sendiri.

\section{Allah Bapa, Putera, dan Roh Kudus}

Dalam konteks Kristiani/Katolik, iman kristiani memiliki karakter monoteismenya yang khas dibandingkan dengan agama- 
Paulus Bagus Sugiyono, Iman Kristiani Kepada Allah Yang Satu

agama lain. Karakter tersebut tidak pernah dapat dilepaskan dengan ajaran tentang Trinitas (Allah Bapa, Putera dan Roh Kudus). Kekhasan ini perlu dijelaskan lebih lanjut supaya tidak menimbulkan kerancuan penghayatan iman. Thomas Michel, seorang Islamolog yang juga ahli di bidang teologi Kristiani, mengatakan bahwa keyakinan inti dalam agama Kristiani sama dengan agama Yahudi dan Islam, yakni Allah itu Satu. Jemaat Kristiani berkeyakinan bahwa Allah yang diimaninya adalah Allah yang sama dengan yang diimani oleh Abraham dan Musa sebagai pendahulu mereka. Namun, Michel menambahkan bahwa "keEsa-an Allah" dalam konsep Kristiani (monoteisme Kristiani) juga terkait dengan sifat ketritunggalan Allah. Dengan kata lain, pembicaraan mengenai Trinitas selalu berada dalam konteks ke-Esa-an Allah.7

Pemahaman konsep ketritunggalan Allah tidak pernah lepas dari sifat misteri. ${ }^{8}$ Akal budi manusia tidak akan mampu menjelaskan secara sempurna dan memuaskan tentang Allah. Sesuatu yang bersifat misteri di satu sisi tetap dapat didekati, namun di sisi lain manusia tetap harus sadar bahwa semua pendekatan tidak akan mampu secara tepat dan presisi merumuskan secara tepat tentang Allah. Meski demikian, pernyataan ini tidak menutup kemungkinan adanya setiap pendekatan dan usaha yang dapat dilakukan manusia untuk mengenal dan menyelami misteri Allah. Dalam kaitan tentang Allah yang merupakan misteri yang tidak terselami, Karl Rahner menjelaskan bahwa di dalam keterbatasan manusia-lah Allah sendiri yang nantinya akan mengangkat manusia dan pengalamannya ke taraf yang lebih tinggi. ${ }^{9}$ Dengan 2001), 55-6.

7 Thomas Michel, Mengenal Lebih Dekat Iman Kristiani (Yogyakarta: USD,

8 Yustinus Ardianto, Mencintai Iman Katolik (Jakarta: Komunitas JOY, 2012), 20.

9 Karl Rahner, The Content of Faith (New York: The Crossroad Publishing Company, 1993), 47. Karl Rahner menuliskan, “... In any case, the true message of Christianity has this to say to us: God is the incomprehensible 
demikian, penulis berpendapat bahwa kemisterian Allah tidak menutup eksistensi diri-Nya sendiri untuk bisa dipahami oleh umat manusia, melainkan membuka seluas-luasnya untuk bisa digali dan dimaknai.

Selain aspek misteri, ada tiga kebenaran iman yang harus dipahami terkait dengan Trinitas. Pertama, umat beriman percaya bahwa dunia ini ada, tidak dengan sendirinya, melainkan diciptakan oleh Allah Bapa yang ada sejak kekal. Kedua, umat beriman percaya bahwa Allah telah menjelma menjadi manusia dalam diri Yesus Kristus, Sang Putera, untuk menyelamatkan manusia lewat hidup, sengsara, wafat, dan kebangkitan-Nya. Ketiga, umat beriman percaya bahwa Kristus telah menganugerahkan Roh Kudus yang merupakan jiwa Gereja. Melalui gereja inilah umat beriman zaman sekarang menerima banyak rahmat yang dibutuhkan untuk memperoleh kehidupan abadi. ${ }^{10}$

\section{Penutup}

Joseph Ratzinger telah memberikan pedoman iman bagi umat Kristiani dalam kehidupan sehari-hari. Pedoman iman itu adalah kepercayaan iman umat Kristiani akan satu Allah yang bersifat Tritunggal Mahakudus. Konsekuensinya, umat Kristiani wajib menolak segala bentuk dan praksis ateisme dan politeisme di zaman ini, misalnya pemujaan yang berlebihan terhadap harta, kekuasaan, nafsu seksual dan politik. Pedoman iman inilah yang diharapkan menjadi pegangan kuat umat Kristiani supaya tidak mudah merelativisir iman. Sebagaimana telah dijelaskan oleh penulis pula dalam tulisan ini, iman Kristiani terhadap Allah yang satu juga mesti dihayati dalam konteks Tritunggal Mahakudus. Persis di sanalah iman Kristiani menemukan kekhasannya.

mystery of our existence which encompasses us and causes us to realize, however painfully, the limitations of that existence, which he himself transcends". 2012), 21.

10 Yustinus Ardianto, Mencintai Iman Katolik (Jakarta: Komunitas JOY, 
Paulus Bagus Sugiyono, Iman Kristiani Kepada Allah Yang Satu

Dalam sejarah panjang karya keselamatan, Allah hadir dan menemani manusia dalam rupa Bapa, Putera dan Roh Kudus.

$$
====0000====
$$




\section{DAFTAR PUSTAKA}

Ardianto, Yustinus. Mencintai Iman Katolik. Jakarta: Komunitas JOY, 2012.

Cahyadi, Krispurwana. Benediktus XVI. Yogyakarta: Kanisius, 2010.

Dister, Nico Syukur. Pengantar Teologi. Yogyakarta: Kanisius, 1991

Jehani, Libertus. Paus Benediktus XVI: Palang Pintu Iman Katolik. Tangerang: Sinondang Media, 2005.

Michel, Thomas. Mengenal Lebih Dekat Iman Kristiani. Yogyakarta: Universitas Sanata Dharma, 2001.

Rahner, Karl. The Content of Faith. New York: The Crossroad Publishing Company, 1993.

Ratzinger, Joseph Cardinal. Introduction to Christianity. San Fransisco: Ignatius Press, 2004.

Rottenberg, Isaac. "Religionless Christianity", http://www.religiononline.org/ showchapter.asp?title $=1752 \& \mathrm{C}=1513$ (diakses tanggal 17 November 2014 pukul 20.52 WIB). 